\title{
The Processes of the Formation of a Gifted Person in Distant Districts of the Arctic: the Digital Age *
}

\footnotetext{
*The article had been prepared on the basis of the research carried out under the theme of the research work 0226-2019-0023 "Scientific basis for the formation and implementation of the financial and investment potential of the North and the Arctic regions"
}

\author{
Natalia Dyadik \\ IES KSC RAS \\ Luzin Institute for Economic Studies KSC RAS, \\ Apatity, Russia \\ ndyadik@mail.ru
}

\author{
Anastasiia Chapargina \\ IES KSC RAS \\ Luzin Institute for Economic Studies KSC RAS, \\ Apatity, Russia \\ achapargina@yandex.ru
}

\begin{abstract}
In the digital age, issues of provided with trained human resources, the effective use of the intellectual potential of a territory and the creation of conditions for its reproduction are particularly important. These problems are exacerbated in distant districts of the Russian Arctic. Digital technologies have become an integral component of education worldwide, so the purpose of this article is to identify possible approaches to the organization of the educational process using digital technologies to improve the quality of education and early detection of gifted children in distant districts of the Arctic. The existing educational environment in the Arctic regions is analyzed in the article. The impact of the degree of urbanization on affordable education in distant districts was assessed. The financial capabilities of the population were investigated. Based on the analysis, some problems associated with the active dissemination of new technologies were identified. Recommendations on improving the educational process taking into account the digitalization of society are given. The main stages of the modernization of the educational process in distant districts of the Arctic are identified. Digitalization will expand the reach of gifted children in distant districts of the Arctic, as they will be able to actively participate in online events that were previously unavailable to them.
\end{abstract}

Keywords - educational environment, digital technologies, distant districts of the Arctic, educational system, gifted children, accessibility of education

\section{INTRODUCTION}

The issue of the formation and development of the human potential of the regions causes close attention as society so as the state. In the age of digitalization and informatization of society, issues of provided with trained human resources, the effective use of the intellectual potential of a territory and the creation of conditions for its reproduction are particularly important. These problems are especially acute in small and medium cities of the Russian Arctic. This fact is primarily due to the specifics of their economic and geographical position in relation to the nearest large urban agglomerations, in which the main educational institutions are concentrated. The rapidly growing digital technology market is creating new challenges for educational institutions. Therefore, the most important qualities of the individual are initiative, the ability to think creatively and find non-standard solutions, the ability to choose a professional path. All it requires the effective identification of the child's giftedness in the early stages of education in order to unlock his potential abilities.

Despite the urgency of the problem of the formation of a gifted person in the framework of the development of human capital, this problem nevertheless remains poorly studied in conceptual terms with a sufficiently high study of its individual aspects. For the first time, issues about the development of human potential were considered in the researches by A. Smith, Y. Petty, D. Ricardo, and K. Marx, and ideas about human potential were changing during the development of science. D. Ricardo and J. Mill believed that the most important role in shaping the human potential capable of generating income in the future was assigned to education, acquired abilities and upbringing [1]. The idea of human capital was further developed in the papers by $\mathrm{T}$. Schultz, G. Becker, W. Bowen, proving that the qualitative characteristics of the labor force in the economic development of society are paramount importance [2]. Today Lipovska H., Odoardi I. and Muratore F. investigate the impact of the educational process on the formation of human capital [3-4]. Considerable contribution to the development of the theoretical foundations of the concept of human potential was also made by modern Russian economists, such as S. Dyatlov, I. Ilyinsky, R. Nureyev, and others.

Together with the problems of human potential development, scientists are attracted by issues related to the formation of gifted children. Analysis of the scientific literature suggests that this problem has always been the focus of attention of scientists. Starting from the papers of K.D. Ushinsky, L.H. Tolstoy, P.F. Lesgafta, S.T. Shatsky the main factor in the development of the personality of the student is an understanding of the developing environment. At the same time, the developing environment was considered only as a phenomenon of extra-school life [5]. The study of the fundamental problems of the structure and nature of abilities, the conditions of their development were engaged in such scientists as A.N. Leontyev V.A. Krutetsky, K.K. Platonov S.L. Rubinstein, B.M. Teplov V.D. Shadrikov and others. Proceedings of A.M. Matyushkina, A.V. Zhigailova, A.I. Savenkova about the historical analysis of studying the problems of giftedness and the practice of working with gifted children in Russia and its regions are considerable interest for 
this research [6]. Applied aspects of identifying extraordinary abilities of children are studied by such scientists as Vogelaar B, Calero M., Adelson J, Smedsrud J., and others. [7-10]. Important methodological issues related to an integrated approach to the problem of giftedness, taking into account its personal components, have been posed by AK. Baymetov, Yu.Z. Gilbukh, N.S. Leites V.S. Yurkevich.

To address the issue of determinism among the development of giftedness is interesting V.I.Panov view. He notes that for the full development of the intellectual and creative abilities of each gifted child, a certain structure of the educational environment and its special design are necessary [11].

Thus, the abundance of scientific papers on the formation of a gifted child reveals both theoretical and applied aspects of identifying talented children. At the same time, the analysis of factors affecting the disclosure of children's potential opportunities in the Russian Arctic is left aside.

In this regard, the main research questions are:

Is it possible to solve the problem of the availability of quality education in distant districts of the Russian Arctic by digital technologies?

If so, how should the educational process is organized?

What role will digital technology play with support of gifted children?

The purpose of this article is to identify possible approaches to the organization of the educational process using digital technologies to improve the quality of education and early detection of gifted children in distant districts of the Arctic.

To achieve this goal, the following tasks are identified: analyze the existing educational environment in the Russian Arctic; to assess the impact of the degree of urbanization on affordable education in distant districts; explore the financial capabilities of the population; give recommendations on the modernization of the educational process taking into account the digitalization of society.

\section{MATERIALS AND METHODS}

To achieve this goal, the methods of statistical analysis, synthesis and comparison were used in the research. The content analysis of the works of domestic and foreign scientists involved in the development of gifted children in a rapidly changing educational environment in the digital age is the methodological basis of the research.

As the object of the research, the regions in whole or in part referred to the Arctic zone of the Russian Federation were selected according to the Decree of the President of the Russian Federation dated May 2, 2014 N 296 "On land territories of the Arctic zone of the Russian Federation".

To analyze the degree of urbanization and educational environment in the Arctic regions, data of the Federal State Statistics Service were used.

The availability of general education in the Russian Arctic was determined with rating, which developed by a group of experts to analyze Russian regional information systems in the general education [12]. The rating shows the current level of automation of educational activities in general education programs in all regions of the Russian Federation and determines the degree of compliance of regional UFTR systems (Unified Functional Technical Requirements for Information systems).

\section{RESULTS}

\section{A. Urbanization level as a factor of education access}

The availability of education is influenced by many factors (economic, territorial, social, etc.). In the Arctic conditions, the research of the territorial factor (place of residence, urbanization level, number of universities in region, etc) is more particular importance, because all the arctic settlements are located in extreme climatic conditions and have a territorial gap and remoteness of the regional centers.

An important indicator of territorial inequality in education is the type and size of the settlement (Table 1). Most of the arctic regions are characterized by relative dispersion of settlements [13].

TABLE I. DISTRIBUTION OF URBAN DISTRICTS AND MUNICIPAL DISTRICTS IN ARCTIC REGIONS OF THE RUSSIAN FEDERATION, 2018.

\begin{tabular}{|c|c|c|c|c|}
\hline \multirow[t]{2}{*}{ Arctic region } & \multicolumn{4}{|c|}{$\begin{array}{l}\text { The number of urban districts and } \\
\text { municipalities with a population of: }\end{array}$} \\
\hline & $\begin{array}{c}>150 \\
000\end{array}$ & $\begin{array}{c}75 \\
000 \\
-150 \\
000\end{array}$ & $\begin{array}{c}10000 \\
-75 \\
000\end{array}$ & $\begin{array}{l}<10 \\
000\end{array}$ \\
\hline Karelia Republic & 0 & 0 & 3 & 0 \\
\hline Komi Republic & 0 & 1 & 0 & 0 \\
\hline $\begin{array}{ll}\text { Nenets } & \text { Autonomous } \\
& \text { District (NAD) }\end{array}$ & 2 & 0 & 3 & 2 \\
\hline $\begin{array}{c}\text { Arkhangelsk region } \\
\text { (without NAD) }\end{array}$ & 0 & 0 & 2 & 0 \\
\hline Murmansk region & 1 & 0 & 12 & 4 \\
\hline $\begin{array}{l}\text { Yamalo-Nenets Autonomous } \\
\text { District }\end{array}$ & 0 & 2 & 8 & 4 \\
\hline Krasnoyarsk Krai & 1 & 0 & 2 & 0 \\
\hline Sakha (Yakutia) Republic & 0 & 0 & 0 & 5 \\
\hline Chukotka Autonomous District & 0 & 0 & 1 & 7 \\
\hline Russian Arctic & 4 & 3 & 31 & 22 \\
\hline
\end{tabular}

The data in Table 1 show that most urban districts and municipal districts have a population of less than 75 thousand people in the Russian Arctic. Тем не менее, анализ соотношения городского и сельского населения показал, что в регионах Арктики преобладающая часть населения проживает в городах (рис.1).

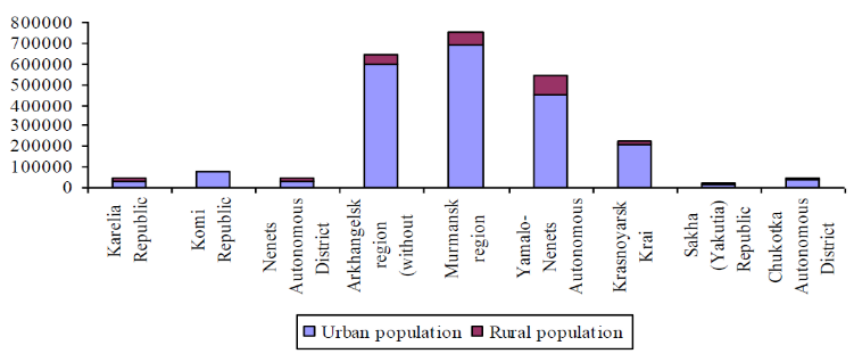

Fig. 1. Urbanization level of Arctic Russia, 2018 
The most "strong" educational institutions are mainly located in the regional (krai, republic) centers. On the contrary, "ordinary" institutions are mainly located in rural, urban-type settlements and regional centers. And in some Arctic territories there are no educational institutions (Karelia Republic, Sakha (Yakutia) Republic, Nenets Autonomous District). For example, in the Nenets Autonomous District there are not only "strong" universities, but no universities at all. This region is the first in the list of regions with least supply level training places for local youth. [14].

There is a low density and high ultradispersity of its settlement in the Arctic regions, despite the relatively high urbanization level (Table 2).

TABLE II. POPULATION AND POPULATION DENSITY IN ARCTIC REGIONS, 2018

\begin{tabular}{|l|c|c|}
\hline \multicolumn{1}{|c|}{ Arctic region } & $\begin{array}{c}\text { Population } \\
\text { (thous. } \\
\text { persons })\end{array}$ & $\begin{array}{c}\text { Population } \\
\text { density } \\
\text { (person per sq } \\
\text { km) }\end{array}$ \\
\hline Karelia Republic & 42.8 & 0.99 \\
\hline Komi Republic & 77.3 & 3.31 \\
\hline Nenets Autonomous District (NAD) & 646.9 & 3.43 \\
\hline Arkhangelsk region (without NAD) & 44.0 & 0.25 \\
\hline Murmansk region & 753.6 & 5.16 \\
\hline Yamalo-Nenets Autonomous District & 538.5 & 0.70 \\
\hline Krasnoyarsk Krai & 227.9 & 0.21 \\
\hline Sakha (Yakutia) Republic & 26.0 & 0.06 \\
\hline Chukotka Autonomous District & 49.3 & 0.07 \\
\hline Russian Arctic & $\mathbf{2 4 0 . , 3}$ & $\mathbf{1 . 3 5}$ \\
\hline
\end{tabular}

The low density of settlement in the Arctic regions increases the service radius and thus makes various services inaccessible to a part of the population, including educational services

\section{B. Analysis of the educational setting}

According to the Rating, which reflects the level of automation of educational activities in general education programs (excluding pre-school), the Arctic regions (with the exception of the Krasnoyarsk Krai and Karelia Republic data are not available) can divide into three groups:

Group 1 - It is regions with a low level of automation of educational activities (Arkhangelsk region and Chukotka Autonomous District);

Group 2 - It is regions which partially conforming to UFTR systems (Murmansk region and Nenets Autonomous District);

Group 3 - It is regions with a high level of automation of educational activities (Sakha (Yakutia) Republic, YamaloNenets Autonomous District and Komi Republic).

The process of informatization and digitalization takes place in different regions at different rates and in depends on many factors. In some regions, only the beginning of equipping educational institutions with computers, and in other regions, educational institutions have already successfully operated in a single information space.

Currently, in almost all the Arctic regions there are not only primary and secondary schools, but also higher institutions (with the exception of the Nenets Autonomous
District). Among the Arctic regions, the Murmansk region is the most numerous, the most highly urbanized and has the highest population density. Therefore, we will analyze the educational environment in the example of the Murmansk region.

Today the Murmansk region has all the steps of the educational process. These are general secondary and special institutions, universities, which training on masters and bachelors, as well as the Federal Research Center, which unites 10 research institutes. In addition, in the Federal Research Center dissertation councils on various specialties are opened. However, in this region has a negative tendency in education for ten years (Table 3 ).

TABLE III. GROWTH RATE EDUCATIONAL ORGANIZATIONS IN THE MURMANSK REGION IN 2005-2018,\%

\begin{tabular}{|c|c|c|c|c|c|c|c|}
\hline $\begin{array}{l}\text { Types of } \\
\text { education }\end{array}$ & $\begin{array}{c}\mathbf{2 0 0 5} \\
/\end{array}$ & $\begin{array}{c}\mathbf{2 0 1 0} \\
/\end{array}$ & $\begin{array}{c}\mathbf{2 0 1 3} \\
/\end{array}$ & $\begin{array}{c}\mathbf{2 0 1 4} \\
/\end{array}$ & $\begin{array}{c}\mathbf{2 0 1 5} \\
/\end{array}$ & $\begin{array}{c}\mathbf{2 0 1 6} \\
/\end{array}$ & $\begin{array}{c}\mathbf{2 0 1 7} \\
/\end{array}$ \\
\hline $\begin{array}{c}\text { Primary, basic } \\
\text { and secondary } \\
\text { general } \\
\text { education }\end{array}$ & -2.2 & -18.7 & -26.5 & -26.1 & -28.3 & -26.1 & -27.0 \\
\hline $\begin{array}{c}\text { Secondary } \\
\text { vocational } \\
\text { education }\end{array}$ & -18.8 & -25.0 & -3.1 & -9.4 & -15.6 & -3.1 & -12.5 \\
\hline $\begin{array}{c}\text { Higher } \\
\text { education }\end{array}$ & -8.6 & -20.0 & -34.3 & -42.9 & -60.0 & -68.6 & -77.1 \\
\hline
\end{tabular}

If in the period from 1990 to 2004 the number of students and higher educational institutions tended to grow [15], then, since 2005, the number of educational institutions in the Murmansk region across all levels of education has decreased dramatically. The negative dynamic is evident even more especially in higher education.

\section{B. Analysis of the financial possibilities population}

Accessibility to educational services is determined not only by the territorial factor and abilities of students, but also by financial possibilities. It is possible to assess the financial capabilities of the population using various indicators, but the main and determining factor is indicator of the income population level We will analyze the dynamics of the average per capita incomes of the population in the Arctic regions over the past eight years:

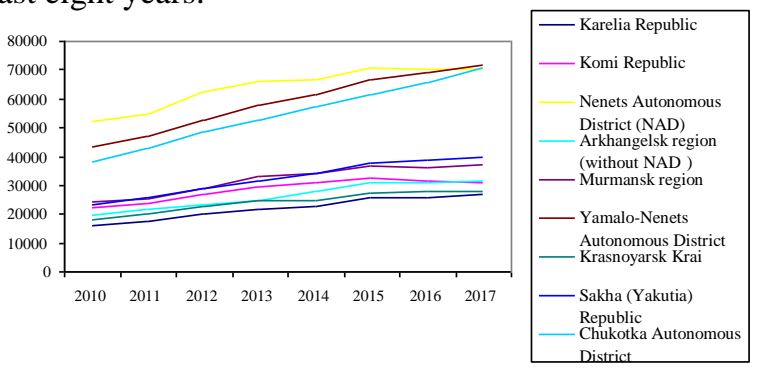

Fig. 2. Dynamics of average per capita population incomes in the Arctic regions, rub.[16]

In the Arctic regions population incomes in absolute terms have a tendency to grow and these incomes are higher Russian average. Considerable deviation income level is observed in the Nenets, Chukotka and Yamalo-Nenets Autonomous Districts (more than 2 times from Russian average). Since 
2013, income growth is slowing both in Russia as a whole and in the Arctic regions. However, it should not be based only on the tendency of growth of incomes of the population in absolute and relative terms when we speak of a satisfactory level of well-being of the population and its financial capabilities.

In fact, the population assesses its standard of living not by the average rate of income growth, but by the growth in the possibilities of meeting their needs at the expense of the income received. To some extent, "purchasing power" of population incomes in a particular region can be determined by the ratio of average income and the minimum subsistence level [17].

If we compare population incomes in the Arctic region with the minimum subsistence level, then we will note that, despite incomes growth, the living standard of the population in the Arctic regions are approaching the Russian average. The negative point is the fact that the growth rate of the subsistence minimum, as a rule, is faster the growth of income (fig.2). Be noted that during the study period, the share of the subsistence minimum in the income of the population grows. This fact gives grounds to assert that the standard of living and financial capabilities of the population are declining.

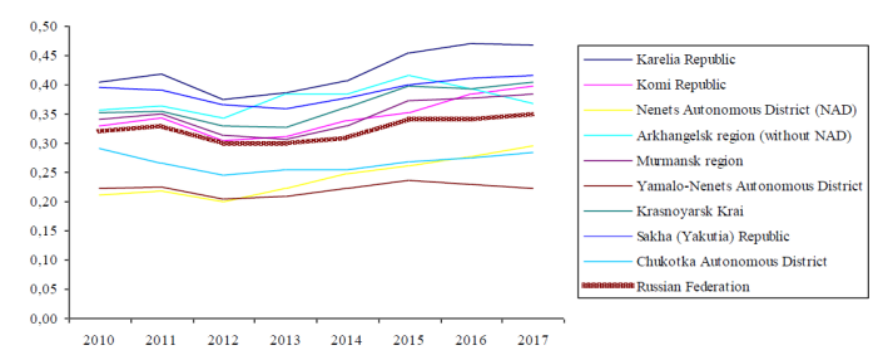

Fig. 3. The ratio of average per capita cash income of the population and subsistence minimum in the Arctic regions

\section{DISCUSSION AND CONCLUSION}

The development of information technologies takes the educational process to a completely new level of development, and digital literacy is becoming an increasingly important component of success for the education and development of a gifted children. However, despite the active introduction of the "digit" in all spheres of human activity, including education, there are some problems associated with the intensive introduction of new technologies.

The first problem is that there is a digital divide in society in the use of technologies at the level of access to the Internet (more wealthy people have more broad digital access [18]) and special skills for applying information innovations. For example, in Russia, online education in schools is 0 per cent versus 3 per cent abroad [19].

The second problem is related to social and economic inequality in digital use for educational purposes. It should be noted that such inequality exists even after achieving equal digital access, and it remains a problem for both high and low income countries [20]. In general, children with higher socioeconomic status are more often using computers for educational purposes, and vice versa, children with lower socio-economic status with more likely are not using digital devices for social networks and games and, therefore, they less prepared for academic knowledge [21-22].

The third problem has to do with a fairly low level of digitalization in the educational process due to geographical remoteness. The problem of "territorial barrier" is associated with territorial mobility. Quality education is most accessible to those who are not "tied to a place" and are ready (and can afford) to "go for the quality" of educational services. For reveal the potential of gifted children, territorial mobility is more important at the phase of receiving general education than at the phase of obtaining higher education.

The problems identified are typical for Russia as a whole, and the specific features of the development of the Arctic regions (including the harsh climatic conditions of residence, the discomfort of living, the dispersibility population, the uneven development of social and transport infrastructure) further compound these problems. Therefore, returning to our main research question, we can say about of certain digital level of the Arctic regions. However, it is too early to say about the quality of education, and even more so about the significant impact of digital technologies on the disclosure of the potential abilities of gifted children.

In order to develop gifted children in distant districts of the Arctic, in the framework of the universal introduction of digital technologies in the educational process, the following measures should be taken:

The modernization the forms of transmission and transfer of knowledge in the educational process, primarily using digital technologies;

The creation of remote training channels for the removal of 'territorial barriers' (video tutorials, online training, etc.);

Enhancing the interaction of government and companies in the commodity sector in the framework of corporate social responsibility, with the aim of attracting investment in education;

Building new forms of communication "region municipal district - educational institution", through the creation of regional centers for gifted children, providing continuous social and pedagogical support for a gifted child in society and the region;

Training of highly qualified personnel for "digital" education, including for organizing the process of supporting the development of a gifted child;

The creation of an information base to support gifted children in the regions.

In the framework of the presented activities, the following phase of modernization of the educational process in distant districts of the Arctic can be identified:

Phase 1 - technical equipment of classrooms (computers, interactive boards, etc.) in the framework of the national project "Education"

Phase 2 - training of the teaching staff of educational institutions in the context of digitalization (seminars, webinars, online courses, etc.) 
Phase 3 - the creation and development of educational portals, allowing to include educational institutions of the Arctic in a single information space of the educational setting.

Thus in the foreseeable future, digital technologies are likely to become the dominant force in society, it is still the most important question about accompanying a gifted children and revealing their abilities in the conditions of the Arctic Digitalization will expand the reach of gifted children in distant districts of the Arctic, as they will be able to actively participate in online events that were previously unavailable to them.

\section{REFERENCES}

[1] S.N. Sakharovskiy, "Institutsional'nyye faktory formirovaniya chelovecheskogo potentsiala" [Institutional factors of human potential formation], Zhur. Instit. Issled. [Jour. of Ins. Stud.], V.2, pp.83-92, 2012

[2] D.V. Sokolova and A.B. Kulakova, "Razvivayushchaya sreda obrazovatel'nogo uchrezhdeniya kak faktor formirovaniya chelovecheskogo potentsiala ekonomiki regiona" [Developmental environment of an educational institution as a factor in the formation of the human potential of the regional economy], Vopr. territ. Razv. [Iss. of Terr. Devel.], V.10 (30), pp.1-13, 2015

[3] H. Lipovska and J. Fischer, "Gifted students and human capital accumulation", Jour. on Eff. and Resp. in Educ. and Sci., T.9, V.3, pp.60-69, 2016, DOI: 10.7160/eriesj.2016.090302

[4] I. Odoardi and F.Muratore, "The role of human capital after the crisis in Italy: A regional analysis", Soc.-eco. Plan. Sci., T.66, pp.58-67, Juny 2019, DOI: 10.1016/j.seps.2018.07.002

[5] D. V. Sokolova, "Professional'naya oriyentatsiya shkol'nikov kak faktor razvitiya chelovecheskogo potentsiala territoriy (na primere nauchno-obrazovatel'nogo tsentra ISERT RAN)" [Professional orientation of schoolchildren as a factor in the development of the human potential of territories], Probl. Razv. Terr. [Prob. of Terr. Dev.], V. 77, pp. 104-114, 2015

[6] A.M. Matyushkin, Odarennost' i vozrast. Razvitiye tvorcheskogo potentsiala odarennykh detey: ucheb. Posobiye [Giftedness and Age. Development of creative potential of gifted children: studies. Benefit]. Izd-vo MPSI [MPhSU: University Science], 2004.

[7] B. Vogelaar, W. Resing, F. Stad and S. Sweijen, "Is planning related to dynamic testing outcomes? Investigating the potential for learning of gifted and average-ability children”, Acta Psych., T.196, pp.87-9, May 2019, DOI: 10.1016/j.actpsy.2019.04.004

[8] M. Calero, G. Belen and M.Robles, "Learning Potential in high IQ children: The contribution of dynamic assessment to the identification of gifted children", Lear. and Ind. Diff., T.21, V.2, pp.176-181, April 2011, DOI: 10.1016/j.lindif.2010.11.025

[9] J. Adelson and M.Matthews, "Gifted Child Quarterly's Commitment to Transparency, Openness, and Research Improvement", Gift. Child Quart., T.63, V.2, pp.83-85, April 2019.

[10] J.Smedsrud, "Mathematically Gifted Accelerated Students Participating in an Ability Group: A Qualitative Interview Study", Front. in Psych.., T9, N. art.1359, July 31, 2018

[11] V.I. Panov, "Yesli odarennost' - yavleniye, to odarennyye deti - eto problema" [If giftedness is a phenomenon, then gifted children are a problem], Nachal. shkola: plyus-minus [Primary School: plus - minus], V.3, pp. 3-10, 2000.

[12] Reyting sub"yektov Rossiyskoy Federatsii po urovnyu avtomatizatsii obrazovatel'noy deyatel'nosti po programmam obshchego obrazovaniya (isklyuchaya doshkol'noye) [Rating of constituent entities of the Russian Federation by the level of automation of educational activities in general education programs (excluding preschool)], Federal'nyy portal "Ross. Obraz." [Federal portal "Russ. Educ.”], Available at: http://www.edu.ru/map/technology/, Referance date: 11.06 .2019
[13] Ye.A. Korchak, Arkticheskaya zona Rossii: sotsial'nyy portret regionov [Arctic zone of Russia: a social portrait of the regions]. Izdvo Kol'skogo nauchnogo tsentra RAN [KSC RAS: Academic Science], 2017

[14] Eksperty nazvali regiony Rossii s samym nedostupnym vysshim obrazovaniyem [Experts called the regions of Russia with the most inaccessible higher education.], January 2017 Available at: https://www.rbc.ru/society/30/01/2017/588f0cab9a794716f7e77440, Referance date: 15.06 .2019

[15] Ye.S. Kotyrlo, "Chelovecheskiy kapital severnykh regionov" [Human Capital of the Northern Regions], EKO [ECO], V.8, pp.68-79, 2008

[16] Regiony Rossii. Sotsial'no-ekonomicheskie pokazateli [Russian Regions/ Socio-economic indicators] Available at: http://www.gks.ru/wps/wcm/connect/rosstat_main/rosstat/ru/statistics/ publications/catalog/doc_1138623506156, Referance date: 14.05 .2019

[17] A.N. Chapargina, "Ob investitsionnoi aktivnosti sberezhenii naseleniya v Arkticheskikh regionakh" [On the investment activity of population savings in the Arctic regions], Sever i rynok: form. Ekonom. Por. [North and the market: The Form. of an Eco. Order], V. 3(54), pp.29-37, 2017

[18] J.KH, T.E. Vachon, \& S. Cheng, "National Income, Political Freedom, and Investments in R\&D and Education: A Comparative Analysis of the Second Digital Divide Among 15-Year-Old Students", Soc. Ind. Res., V. 144, Is. 1, pp 133-166, July 2019, DOI.org/10.1007/s11205-018-2030-0

[19] Issledovaniye rossiyskogo rynka onlayn - obrazovaniya i obrazovatel'nykh tekhnologiy [Research of the Russian market of online education and educational technologies], Available at: http://files.runet-id.com/2017/rif/presentations/19apr.rif17-2.3dreval.pdf, Referance date: 29.05.2019

[20] M. Hilbert, "When is cheap, cheap enough to bridge the digital divide? Modeling income related structural challenges of technology diffusion in Latin America", World Devel., V.38(5), pp. 756-770, 2010

[21] Measuring the information society. Geneva: ITU, Available at: http://www.itu.int/en/ITU-

D/Statistics/Pages/publications/mis2011.aspx., Referance date: 14.06.2019

[22] A. van Deursen \& J.van Dijk, "The digital divide shifts to differences in usage", New Media and Society, V.16(3), pp.507-526, 2014. 